\title{
SCIENTIFIC VALUES OF LANDFORMS AS THE BASIS FOR THE DECLARATION OF PROTECTED SITES (A CASE STUDY OF MT. KRAVÍ HORA IN THE NOVOHARDSKÉ HORY MTS., CZECH REPUBLIC)
}

\author{
RYPL, J. ${ }^{1^{*}}-$ KIRCHNER, K. ${ }^{2}$ \\ ${ }^{1}$ Department of Geography, Faculty of Education, University of South Bohemia \\ Jeronýmova 10, 37115 České Budejovice, Czech Republic \\ (phone: +420-387-773-059) \\ ${ }^{2}$ Institute of Geonics, CAS, v.v.i. Branch Brno \\ Drobného 28, 60200 Brno, Czech Republic \\ (phone: +420-545-422-730) \\ *Corresponding author \\ e-mail:rypl@pf.jcu.cz \\ (Received $31^{\text {st }}$ Oct 2016; accepted $24^{\text {th }}$ Apr 2017)
}

\begin{abstract}
Environmental geomorphology contributes significantly to understanding of the relationship between the effects of human activities, landforms, and geomorphologic processes as well as offers practical solutions for demands of application sphere. This article presents information about scientific values on unique sites - Mt. Kraví hora in the Novohradské hory Mts. (the Czech Republic). The study locality represents an area, which had restricted access prior to 1989 and it is also one of the reasons why the scientific value of the site was preserved in perfect form. Among the preserved scientific values rank landforms such as castle koppies, frost-riven cliffs, blockfields, a mushroom's rock, etc. These perfectly preserved landforms (scientific values) sites led to the declaration of the site as a Geomorphologically Significant Site in the Czech Geological Survey of 2002.
\end{abstract}

Keywords: geomorphological inventory, geomorphologically significant sites, geoeducation, geotourism, geoconservation

\section{Introduction}

In recent times, the issues of environmental geomorphology have been widely used within the application sphere as well as some new approaches which can be included into the environmental (or applied) geomorphology (e.g. geomorphosite concept) and also serve for geoconservation, geoeducation and geotourism purposes.

Environmental geomorphology is ranked as a sub-discipline of geomorphology (Goudie, 2004). According to Coates (1971), environmental geomorphology is defined as the practical use of geomorphology for the solution of problems where humans aim to transform, use or change surface processes and landforms. Environmental geomorphology also includes the evaluation of landforms in terms of their specific use as well as the utilization of geomorphology in the evaluation of environmental impacts (Panizza, 2004; Trenhaile, 2007) and other issues concerning the relationships between human impact and environment (Slaymaker, 2000; Slaymaker et al., 2009).

The evaluation itself (i.e. attributing values to the particular landform or geomorphological landscape) offers the possibility of how to discover the potential of a landform/landscape from specific points of view. According to Reynard et al. (2007, 2016), there are two groups of values to be attributed to a landform: scientific and 
added/additional ones (in literature, e.g. Bruschi and Cendrero, 2005; Serrano and González-Trueba, 2005; Pereira et al., 2007; Coratza et al., 2012, there are more groups of values, but for the purposes of this article we only use one group). The scientific value comprises of criteria such as integrity, rarity, uniqueness, lithological and morphological diversity, palaeogeographical importance or exemplarity (which is the most important issue for geoconservation and geoeducational potential). Thus, the scientific value of a landform or landscape can be considered the fundamental value, which serves as the basis for geoconservation, geoeducation and geotourism purposes (Bajer et al., 2016; Cetiner et al., 2017; Migoń et al., 2017; Pánek, 2016).

The detailed procedure of the declaration of protected sites is described below and generally, it encompasses several steps: inventory and mapping, detailed description of a landform and the declaration of protected sites itself.

In the Czech Republic, there are a number of attractive regions with unique granitic landforms. The Jizerské hory Mountains belong between granite areas with sufficiently large protection of the landscape area (Migoń, 2016). Additionally, the Giant Mountains and the Podyjí area belong between granite areas with sufficiently large protection of the National Park (Fig. 1.). Sufficiently large protection has been missing in the Novohradské hory Mountains up to now, despite that the Novohradské hory Mountains are located in a unique area with well-preserved, unparalleled, spectacular granite landforms and have retained a wide range of its indigenous ecosystems, often with rare preserved fauna and flora associations, along with other interesting landforms in the Czech Republic. The main reason for this situation is inaccessibility and the marginal position of the area within of the position the Czech Republic in central Europe before 1989.

Scientific research has commenced with the aim of proposing this area to be declared a protected landscape area due to the increased interest from investors in the recreational as well as industrial sphere within the entire Novohradské hory Mountains region after 1989. The Czech government rejected the proposal in 2005.

The area-wide land protection of the Novohradské hory Mountains therefore has put forth a solution as a compromise. In 2003, the Council of the South-Bohemian region issued a regulation declaring the entire Novohradské hory Mountains region a natural park. This form of protection enables the Council to partially influence local planning processes in the area.

In the scope of the NATURA 2000 program, the Czech government has declared the Novohradské hory Mountains a birding area in addition to two localities of European significance: Žofínský prales - Pivonické skály and Horní Malše. Under Act no. 114/1992 Coll. localities with the rarest fauna and flora associations have been proclaimed local protected areas (e.g. NNR Žofínský prales, NNP Hojná Voda, NP Myslivna, NP Ulrichov etc.). The absence of any local protected areas under the Act with abiotic subject matter is surprising. Because of this, the research of the Novohradské hory Mountains included a geomorphological inventory survey with the purpose of GPS mapping.

This paper focuses on the scientific values of a typical site, Mt. Kraví hora in the northeastern part of the Novohradské hory Mountains, which is a unique example of the manifold complex of the landforms on granites.

\section{Aim of study}

The aim of this study was to undertake the characteristics of scientific values of granite landscape landforms at the selected locality in the Novohradské hory Mountains 
and in case of confirmed presence of qualitatively as well as quantitatively significant rock forms, to propose a form of protection under the nature protection system of the Czech Republic.

\section{Materials and methods}

\section{Regional settings}

Mt. Kraví hora is situated within the geomorphological unit of the Novohradské hory Mountains. According to the geomorphological classification of the Czech Republic, the unit Novohradské hory Mts. belongs to the Šumava System (Balatka and Kalvoda, 2006; Demek and Mackovčin, 2006), while a wider part of this unit is located in Austria, called Freiwald, which is part of the "Granit- und Gneis-Hochland" extending southwards to the Danube. The location of Novohradské hory Mountains within the scope of the Czech Republic and its basic geomorphological regionalisation is represented in Figure 1.

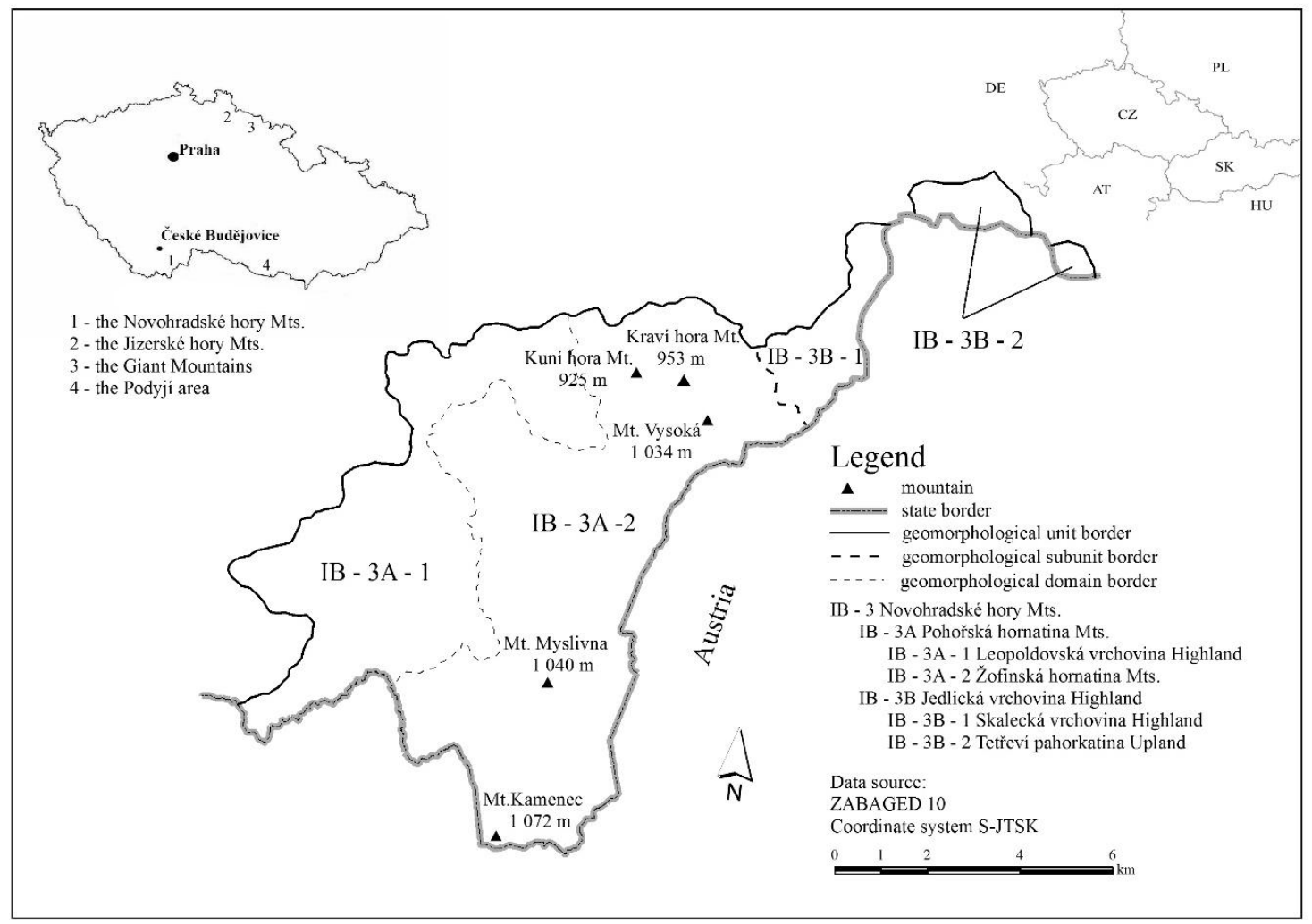

Figure 1. Location of the Novohradské hory Mts., the Jizerské hory Mts., Krkonoše (the Giant

Mountains) and the Podyji area within the scope of the Czech Republic and the basic geomorphological regionalisation of the Novohradské hory Mts. (Balatka \& Kalvoda, 2006; with modifications). Source: Rypl et al. (2015)

From a geological perspective, the area of the Novohradské hory Mountains stretches across the southern part of the Moldanubian Pluton (Pavlíček, 2004). Late Variscan magmatites of this magmatic body cover the largest area within the Novohradské hory 
Mountains and they are represented by several types (e.g. the Weinsberg type granite, the Mrákotín type granite), and partly covered with cordierite gneisses and nebulitic migmatites, which are the remains of the original pluton mantle (Heřmánek and Matějka, 1998). The crystalline basement of the Moldanubicum is the oldest geological unit of the territory, dominated by heavily metamorphosed gneisses and migmatites, sometimes with numerous inserts of quartzite, marble, amphibolite, orthogneiss and other material (Cháb et al., 2008).

The massifs of Mt. Vysoká, Mt. Kraví hora and Mt. Kuní hora (northern part of the Novohradské hory Mountains) and the massifs of Mt. Myslivna and Mt. Kamenec (southern part of the Novohradské hory Mts.) are made of the medium-grained biotitic granite, known as Weinsberg type granite (Staník, 1991; Vrána, 1987; Cháb et al., 2008).

The basic relief of the Novohradské hory Mts. has characteristic elements of a faultblock mountain range with delimitations marked strongly by erosion, whereas it is also clearly polygenetic. It is possible to find here recent forms (rounded blocks of different size, alcoves, grooves), as well as fossil forms (exfoliation joints, tors, frost-riven cliffs, etc.) (Demek and Mackovčin, 2006; Huber, 1999; Chábera and Huber, 1999; Rypl et al., 2015).

\section{Methodological approach}

The evaluation of the scientific value results from the geomorphological inventory and it consists of several steps:

1) preparatory works

2) fieldwork - inventory and mapping

3) final works and evaluation of results

The preparatory works were based on the literature research and analysis of the existing resources related to geological and geomorphological conditions of the area (Heřmánek and Matějka, 1998; Pavlíček, 2004; geological maps 1:50 000 freely accessible at www.geology.cz.). Information about rock landforms geomorphology was based on eg. Huber 1999; Chábera and Huber 1999; Migoń et al. 2017; Rypl 2013; Rypl et al. 2015; Vítek, 1995.

The second phase was based on field research at Mt. Kraví hora and it encompassed a detailed inventory of the particular landforms, morphometrical analysis and geomorphological mapping. The method for the detailed geomorphological inventory is based on various resources (e.g. Coratza et al., 2011; Kirchner and Roštínský, 2007; Kirchner and Kubalíková, 2011 and 2013; Kubalíková, 2009 and 2013; Kubalíková and Kirchner, 2016). The inventory contains information about localization, basic geological settings, description of the morphographic characteristics of the main landforms structures (including mesoforms and microforms). Human influence with its negative impact on the abiotic sector of nature has been also considered. The inventory is accompanied by photodocumentation. The results of the geomorphological inventory are applicable in the area of basic knowledge regarding rare or significant landforms and also in the application area where landscape management arrangements are being proposed in order to protect these landforms, or to remove or diminish any negative impact of human activity in the area of interest.

Concerning the morphometric analysis, simple measuring devices (telemeter HD 150, measuring tape, geological compass) were used to describe the morphometric characteristics of the landforms. In addition, detailed GPS mapping using Garmin GPS 
V Deluxe was undertaken based on Condorachi (2011), Smith et al. (2011), Voženílek et al. (2001).

The geomorphological mapping comes out from the method with emphasised mapping of structure; denudational and accumulation rock landforms described by Bezvodová et al. (1985), Demek et al. (1972) and Smith et al. (2011).

The third and final phase of the evaluation of the scientific value consisted of field data evaluation with emphasis placed on relief rock forms. All field data contain information about localization, basic geological description, description of the main landforms, structures, impact of anthropogenic activity and a proposal of protection. The text is accompanied by a photographic documentation. Landforms were classified terminologically and genetically according to the common geomorphological practice (Demek, 1972; Demek, 1987; French, 2007; Goudie, 2004a, b; Summerfield, 1991; Thomas and Goudie, 2000). The geomorphological map was accompanied by a legend after Létal (1998) which was complemented by key signs missing in the original (e.g. a sign form for castle koppies). Both the geomorphological map and the legend were processed electronically for ArcGIS 9.1 under the ArcView license.

There are specific and unique reliefs in the Novohradské hory Mountains with many significant localities (e.g. Mt. Myslivna, Mt. Kamenec and Mt.Vysoká,). Mt. Kraví hora was selected as a typical illustration locality that contains the key granite landforms.

\section{Results - characteristics of scientific values of landforms on Mt. Kraví hora (953 m a.s.l.)}

\section{Location}

The top of Mt. Kraví hora is found about 500 m west of Hojná Voda. Located near the Austrian border, it stretches in the cadastral area of a municipality of the same name. It is among the rather high tops of the Novohradské hory Mountains and one that in terms of geomorphological hierarchy lies in the northeastern part of the geomorphological district of the Žofínská hornatina Mountains, which is part of the geomorphological sub-unit of the Pohořská hornatina Mountains; one that belongs under the geomorphological unit of Novohradské hory Mountains. (Demek and Mackovčin et al., 2006; Balatka and Kalvoda, 2006). Mt. Kraví hora is a drainage divide of the rivers Črná and Stropnice running across the Mt. Kraví hora; its eastern to northwestern slopes belonging under the basin of the latter. The eastern slope is drained by the stream of Pasecký potok, while the stream of Bedrichovský potok stream functions for the northwestern slope in the same way. The south-facing slopes belong under the basin of the River Černá, more specifically the stream of Lužní potok, the river's right-bank tributary. Mt. Kraví hora is covered mostly by spruce monocultures; in its top parts, one can record valuable specimens of European silver fir with an admixture of European beech.

\section{Basic geological characteristics}

The Novohradské hory Mountains are not too varied in terms of geological composition. Of the largest extent, the late Variscan magmatites of the Central Moldanubian Pluton are represented by several types (granites of Weinsberg and Mrákotín types or granodiorite of Freistadt type), which are partly covered with cordierite gneisses to nebulitic migmatites, the remains of the original pluton mantle. As 
a site, Kraví hora Mountain consists of granite of the Weinsberg type (Heřmánek and Matějka, 1998; Pavlíček, 2004).

\section{Characteristics of the main landforms}

Mt. Kraví hora forms a bornhardt (Fig. 2). This is a major top, separated from the two neighbouring tops (Mt. Vysoká, Mt. Kuní hora) by distinct saddles. The eastern to northeastern slope of the mountain is tectonically determined (Demek, 1972) with a slope of over $20^{\circ}$, passing in places to a 10 to $20^{\circ}$ inclination. The remaining slopes are erosion-denudational slopes, of which the inclination is over $20^{\circ}$ for the northwestern slope, and $10-20^{\circ}$ for the western to southwestern slope. A smaller surface of a $5-10^{\circ}$ slope is possible to define as part of the latter; the place where an unnamed stream springs. In the southwestern and southeastern parts of the mountain, slopes transform into the aforementioned distinct saddles (Rypl, 2015).

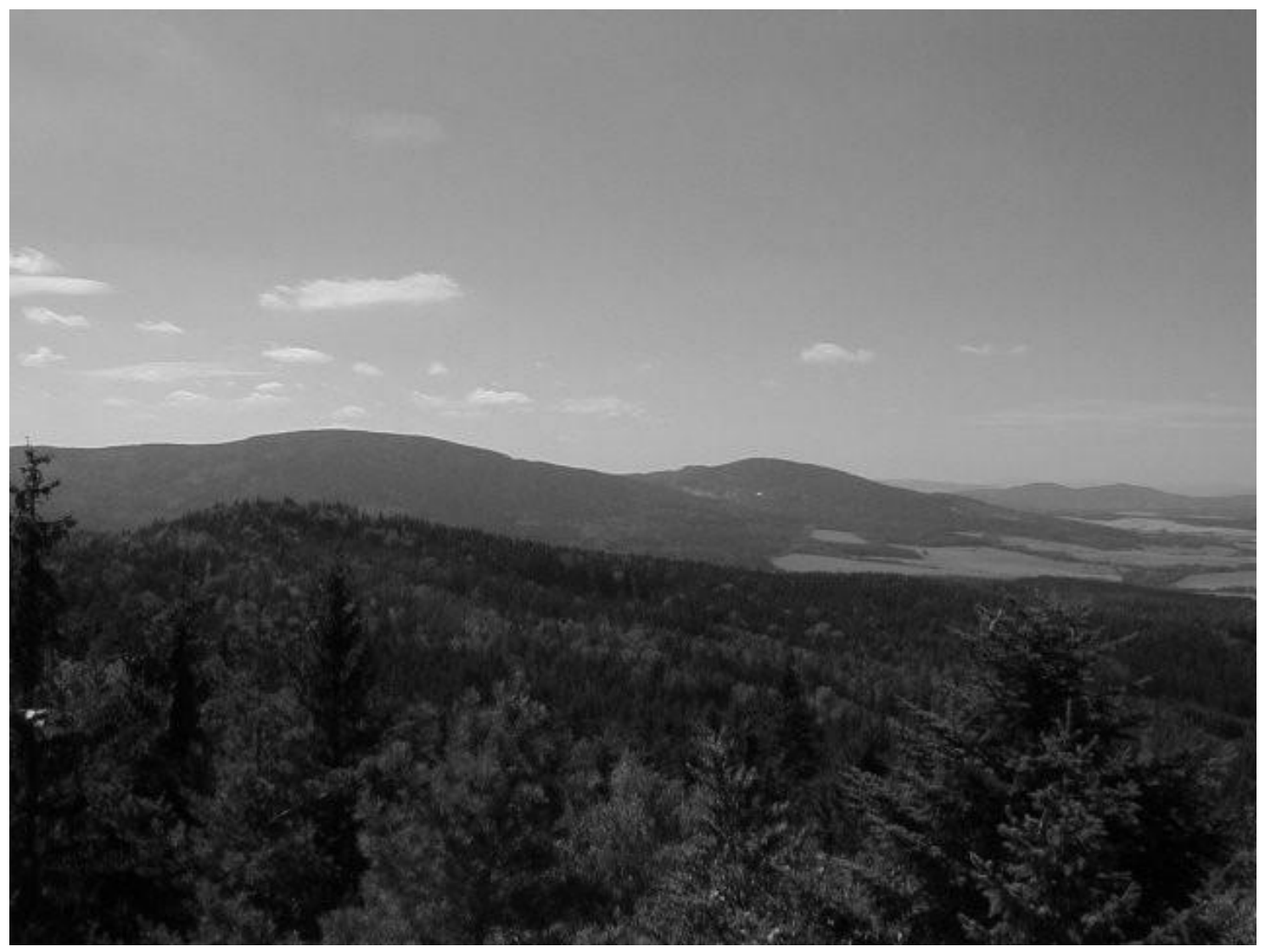

Figure 2. The view on Mt. Vysoká and Kraví hora Mt. from Mt. Mandelstein (AUT)

The actual mountaintop is represented by a castle koppie (Fig. 3) $85 \mathrm{~m}$ long, $3 \mathrm{~m}$ wide and $15 \mathrm{~m}$ high. The formation is bound by a significant nivation hollow in its western part (length $50 \mathrm{~m}$, width $25 \mathrm{~m}$ ); the eastern part turning directly into a tectonically determined slope with an inclination of more than $20^{\circ}$. In addition, the upper parts of the slope near the mountaintop contain two smaller castle koppies measuring $30 \times 6 \times 12 \mathrm{~m}$ and $15 \times 5 \times 12 \mathrm{~m}$. 
The southern edge of the top castle koppie and the nivation hollow is followed by a line of frost-modelled rocky landforms, which stretches to the southeast/south and has a total length of $400 \mathrm{~m}$ (Rypl, 2015).

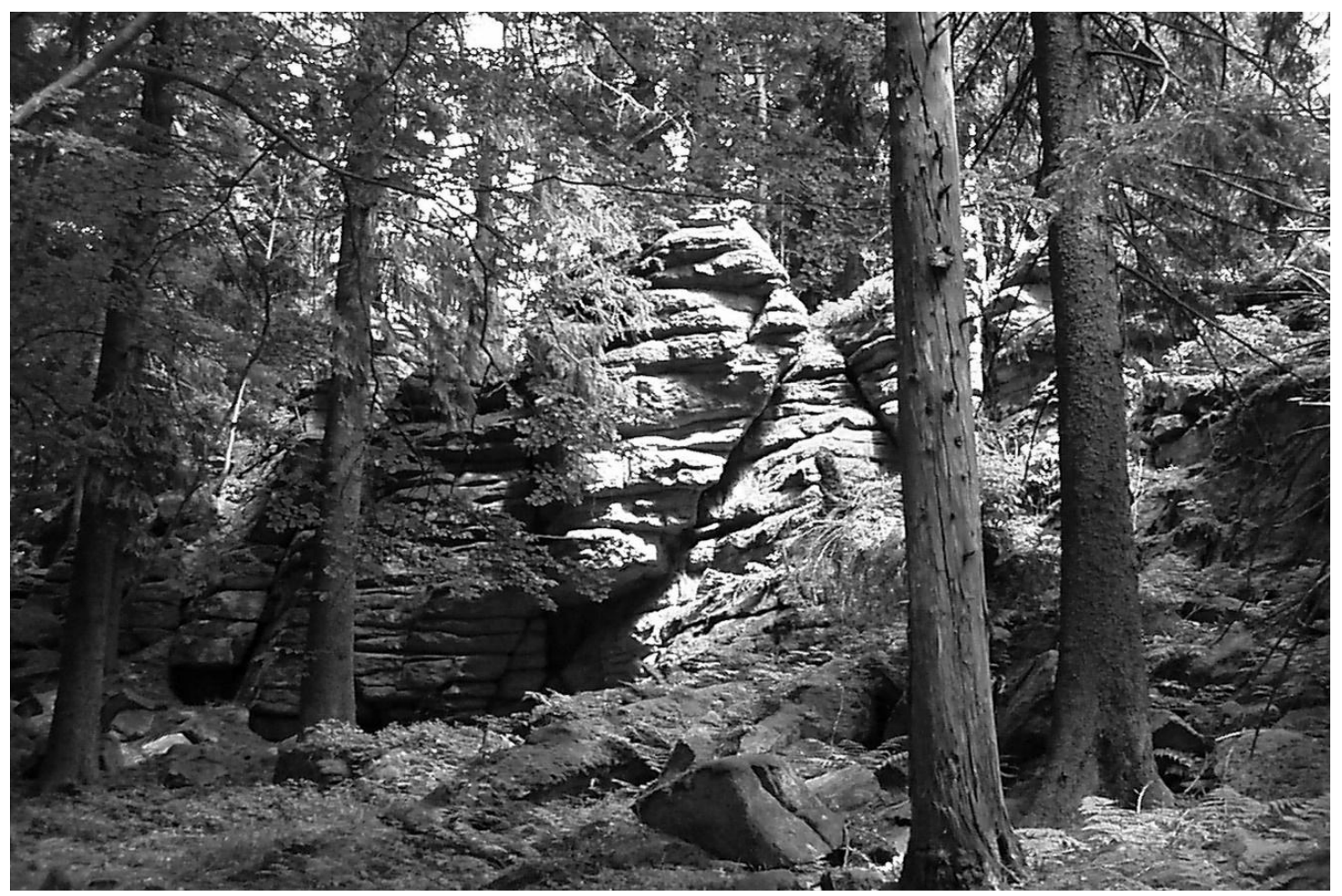

Figure 3. The castle koppie on the top of Mt. Kravi hora

The top castle koppie and the nivation hollow immediately connects to a narrow cryoplanation terrace $(130 \times 30 \mathrm{~m})$, bound by two castle koppies from the west and by a system of frost-riven cliffs from the east. The upper part of the cryoplanation terrace developed a low castle koppie with a length of $40 \mathrm{~m}$ and a height of $3 \mathrm{~m}$; at its southern end is a mushroom`s rock called "Napoleon's Head" that measures 4 x 4 x $10 \mathrm{~m}$. Twenty metres to the south, the shapes outlined above connect to a $100 \mathrm{~m}$ long, $3 \mathrm{~m}$ wide and $15 \mathrm{~m}$ high castle koppie. Three frost-riven cliffs, demarcating the terrace from the east, are about $20 \mathrm{~m}$ long and 6-10 $\mathrm{m}$ high. A rugged castle koppie also extends to the south; it is $40 \mathrm{~m}$ long; its width ranges between 3 and $15 \mathrm{~m}$ and it reaches a height of 13 m (Rypl, 2015).

The numerous manifestations of exfoliation on rocky forms of relief within the line described suggest that it is a structurally determined line, that has its continuation on the northern slope of Mt. Kraví hora. It can also be assumed that the individual shapes formed a single unit in the earlier period and that the splitting was caused by cryogenic processes as late as the cold periods of the Pleistocene.

A cryoplanation terrace measuring $100 \times 140 \mathrm{~m}$ stretches from the south to a southeast slope between contour lines of $885 \mathrm{~m}$ and $870 \mathrm{~m}$. The southern edge of the terrace is subsequently represented by a layer of a discontinuous frost-riven cliffs with a total length of $50 \mathrm{~m}$ and a height of 3.5-10 m. The relatively large blocks of weathered rock (the longest dimension of up to 2 metres) formed from those frost-riven cliffs 
create a pile of angular rock fragments in the steepest part which further turns into a broader blockfield as the slope decreases (Rypl, 2015).

On the eastern tectonically determined slope, there are some smaller-sized cryogenic landforms compared to the shapes mentioned above. These involve several frost-riven cliffs 5-15 $\mathrm{m}$ long and 2-5 m high, except one, which is $20 \mathrm{~m}$ long and $10 \mathrm{~m} \mathrm{high}$; it lies at an elevation of $910 \mathrm{~m}$. For accumulation shapes, there are two block streams, both starting approximately at an elevation of $890 \mathrm{~m}$; they are around $30 \mathrm{~m}$ wide and up to $100 \mathrm{~m}$ long. A structural outcrop occurs further to the north, taking the form of a ruware, which was split into two parts as result of frost weathering. The ruware is elongated in the NE-SW direction and has an overall length of about $100 \mathrm{~m}$. The length of the part located higher is $70 \mathrm{~m}$ with a height of up to $7 \mathrm{~m}$, while the lower portion is approximately $35 \mathrm{~m}$ long, more weathered, and is up to $5 \mathrm{~m}$ high) (Rypl, 2015).

On the northern slope are both cryogenic and structural forms of land relief. Representing the cryogenic forms are three frost-riven cliffs 10 to $15 \mathrm{~m}$ long and 5-8 m high. Faces of two cliffs are oriented to the northeast, while the third one faces northwest. All the cliffs are structurally determined, which is suggested through the significant exfoliation. Structural forms are present with ruwares, which, however, have suffered considerable weathering; specifically, their upper parts became frost-riven cliffs in nature. Both ruwares are based on a common plexus at an elevation of $920 \mathrm{~m}$. The first of them follows the NW-SE direction and its total length is $200 \mathrm{~m}$. More distinct, however, is its upper portion; $100 \mathrm{~m}$ long, the height varies between $3 \mathrm{~m}$ for the lower-elevation section and $8 \mathrm{~m}$ for the upper-elevation part. The other ruware reaches a length of approximately $100 \mathrm{~m}$; following a NNE-SSW direction, it has been heavily remodelled through cryogenic action. The site of this ruware with the nature of a frostriven cliff reaches a height of $12 \mathrm{~m}$ (Rypl, 2015).

The western erosion-denudational slope is covered with a large blockfield throughout its area. In the blockfield are two 10 x $4 \mathrm{~m}$ frost-riven cliffs developed at elevations of 910 and $920 \mathrm{~m}$. The cryoplanation terraces of these cliffs are minor. Elevations of approximately 875 and $850 \mathrm{~m}$ feature two frost-riven cliffs as well; they measure $10 \mathrm{~m}$ in length and their height is $3 \mathrm{~m}$ and $6 \mathrm{~m}$ for the upper cliff and the lower-elevation cliff, respectively. This part located at the borderline of erosion-denudational slopes of 10$20^{\circ}$ and the slope with an inclination of $20^{\circ}$ contains a large and isolated rock formation - a tor. It measures $20 \times 10 \mathrm{~m}$ and its height is about $20 \mathrm{~m}$. While its eastern side, i.e. that facing the top of Kraví hora Mountain, is rather gradual, the other sides are steep with numerous overhanging blocks. The cryogenic landforms are accompanied by numerous rock ledges and laths throughout the site. The distribution of the landforms on Mt. Kraví hora is depicted in Figure 4.

\section{Character of rock structures}

A total of 102 measurements of the fissure system were taken on Mt. Kraví hora (Table $1 a$ and $1 b$ ) and a rose diagram was constructed (Fig. 5). These measurements represent an almost ideally-developed regular fissure system. The NW-SE direction is predominant (with a prevailing direction of $140^{\circ}$ ), accompanied by an almost perpendicular NE-SW direction (with a prevailing direction of $40^{\circ}$ ). In these massive and morphologically distinct fissures, some of them being involved in segmenting the cryogenic landforms into distinctive units, the running directions were postulated to present the primary fissure system. The secondary system is subsequently represented by an assemblage of minor fissures with the direction of $10^{\circ} / 110^{\circ}$. 


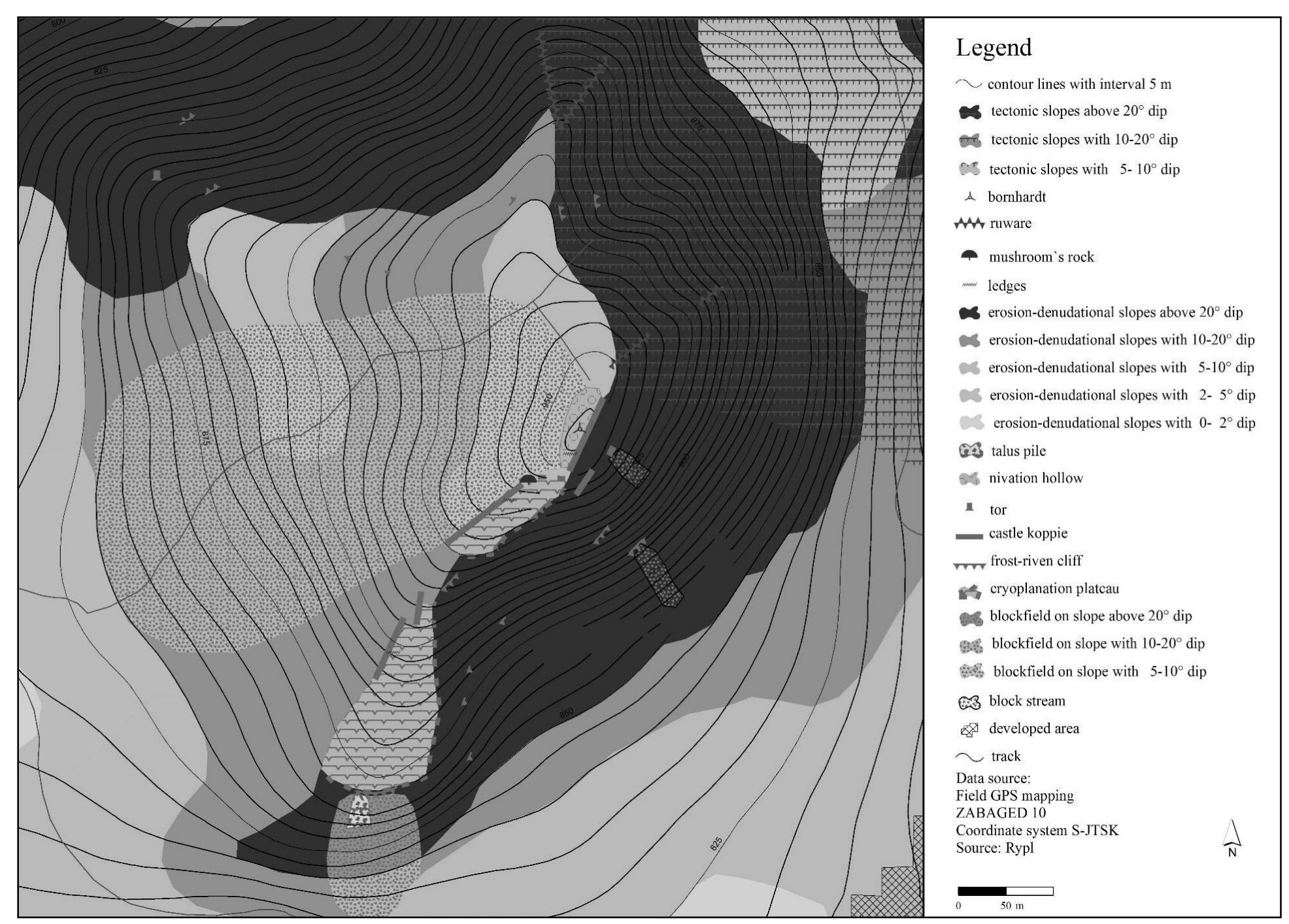

Figure 4. The geomorphological map of Kravi hora Mt. Source: Rypl (2015)

APPLIED ECOLOGY AND ENVIRONMENTAL RESEARCH 15(3):1537-1550. http://www.aloki.hu • ISSN 15891623 (Print) • ISSN 17850037 (Online) DOI: http://dx.doi.org/10.15666/aeer/1503_15371550

๑) 2017, ALÖKI Kft., Budapest, Hungary 
Table 1a. Number of measurements of fissure system with a 0-90 interval at Kravi hora Mt.

\begin{tabular}{|l|l|c|c|c|c|c|c|c|c|c|}
\hline Direction & $\mathbf{0}^{\circ}$ & $\mathbf{1 0}^{\circ}$ & $\mathbf{2 0}^{\circ}$ & $\mathbf{3 0}^{\circ}$ & $\mathbf{4 0}^{\circ}$ & $\mathbf{5 0}^{\circ}$ & $\mathbf{6 0}^{\circ}$ & $\mathbf{7 0}^{\circ}$ & $\mathbf{8 0}^{\circ}$ & $\mathbf{9 0}^{\circ}$ \\
\hline No. of measurements & 3 & 6 & 2 & 9 & 12 & 6 & 6 & 6 & 4 & 3 \\
\hline
\end{tabular}

Source: Rypl (2013)

Table 1b. Number of measurements of fissure system with a 100-180 interval at Kraví hora Mt.

\begin{tabular}{|l|c|c|c|c|c|c|c|c|c|}
\hline Direction & $\mathbf{1 0 0}^{\circ}$ & $\mathbf{1 1 0}^{\circ}$ & $\mathbf{1 2 0}^{\circ}$ & $\mathbf{1 3 0}^{\circ}$ & $\mathbf{1 4 0}^{\circ}$ & $\mathbf{1 5 0}^{\circ}$ & $\mathbf{1 6 0}^{\circ}$ & $\mathbf{1 7 0}^{\circ}$ & $\mathbf{1 8 0}^{\circ}$ \\
\hline No. of measurements & 3 & 6 & 5 & 7 & 9 & 7 & 5 & 3 & 3 \\
\hline
\end{tabular}

Source: Rypl (2013)

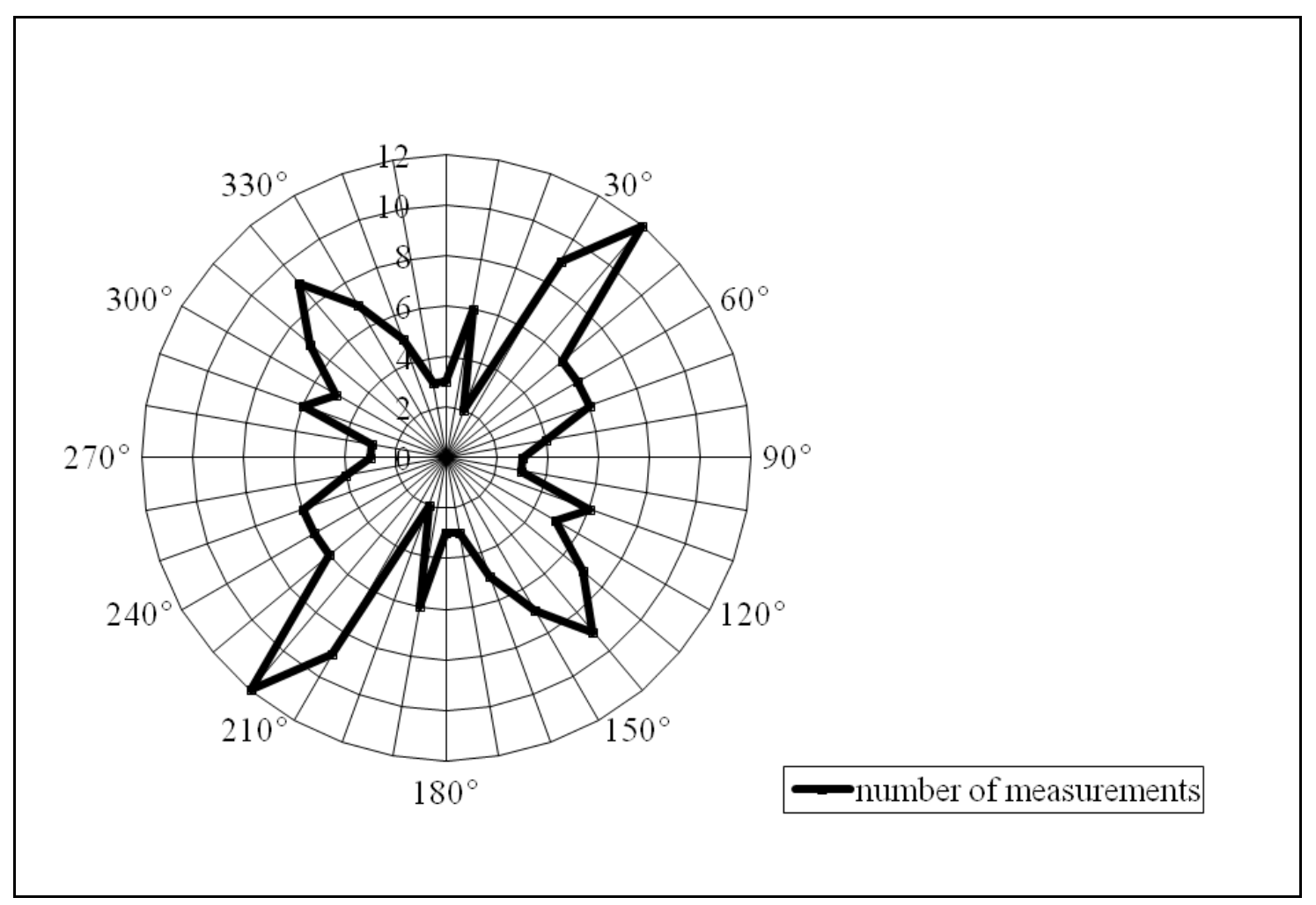

Figure 5. Rose diagram of fissure system of Kravi hora Mt. Source: Rypl (2013, 2015)

\section{Impact of anthropogenic activity}

Kraví hora Mountain is easily accessible from Hojná Voda. There is a hiking trail leading over the mountaintop, which is very often used, particularly in the summer season over the period of the main school holidays. As a result, there is considerable trampling and disturbance of the soil cover in the immediate vicinity of major landforms, i.e. the top castle koppie and the "Napoleon's Head" mushroom`s rock. "Napoleon's Head" is also used by climbers; climbing lugs have been installed, thus setting out climbing routes. The mountaintop very frequently has a large quantity of trash left by hikers that clutters the immediate vicinity. There is also a 
telecommunication tower located at the top and this is accessible via a broad, paved road leading from the southwest.

\section{Proposal to protect the landforms}

In 2003, the territory of the Novohradské hory Mountains was declared as Natural Park by the Regional Authority in České Budějovice. Since this legal status does not provide sufficient protection of the unique and remarkable rock landforms (the "Napoleon's Head" mushroom rock and castle koppies) occurring at the top area of Mt. Kraví hora, the site was included into the Database of the geological localities of the Czech Geological Survey (http://lokality.geology.cz/1191) as a "site recommended for legal protection".

\section{Conclusions}

The evaluation and characteristics of scientific values that can be included into environmental geomorphology can serve as a tool of establishing geotourism, geoeducation and geoconservation (e.g. declaration as a "site recommended for legal protection" in the Database of the geological localities of the Czech Geological Survey).

The evaluation and characteristics of scientific values of the site of Mt. Kraví hora in Novohradské hory Mountains was based on the detailed inventory, fieldwork, morphographical and morphometrical analysis and geomorphological mapping - these steps were necessary for the evaluation and characteristics themselves. Moreover, these steps also helped to complete the geomorphological knowledge about the borderland mountains in south-western and southern part of Bohemia.

The area was part of the "Iron Curtain" during the "Cold War", which means that it was practically inaccessible so that research before 1989 could not be carried out here. As a result, no intensive anthropogenic activity took place in the area during this period and the rich diversity of nature was preserved. This area also deserves increased attention for other reasons than a particular diversity of relief. The first reason is a progressive inclusion of Czech protected areas in the system of nature protection of the European Union. The landscape area of the Novohradské hory Mts. with its variety of aesthetic and natural values is protected by law no. 114/1992 in the category of the 'Natural Park'. Secondly, it is anticipated that there will be interference with the natural environment due to the development of many investment projects, which are expected with post-1989 regional development, particularly in the area of tourism. From these reasons, this area has become the target of multilateral and necessary scientific research (e.g. Malíček and Palice, 2013; Huber, 1999; Chábera and Huber, 1999; Rypl et al., 2015; Štykar, 2005).

The site of Mt. Kraví hora is a good example of the complex landforms on granite transformed by cryogenic processes accompanied by other cryogenic (respectively polygenetic) mesoforms (tors, frost-riven cliffs, block accumulations). Its tourist potential is fully developed, but its geoeducational and geotourist potential has still not been recognized. Recognizing and assessing the scientific value is a basis for the educational and geotourist activities, which can help promote the acceptance of the conservation measures of the site (besides the intentions of the legal protection). 
Acknowledgements. Research could not have been undertaken without the financial support of the grant University of South Bohemia no. 160/2016/S. Special thanks to Cynthia Jonas for notes and revisions.

\section{REFERENCES}

[1] Act No. 114/1992. - Collection of Laws of the Czech Republic.

[2] Bajer, A., Kirchner, K., Kubalíková, L. (2016): Geodiversity values as a basis for geosite and geomorphosite assessment: a case study from Ždárské vrchy highland. - In: Lněnička, L. (ed.) Cenral Europe Area in view of Current Geography (23rd.). - Central European Conference, Brno, Czech Republic, 08. - 09. 10. 2015, p. 56-69.

[3] Balatka, B., Kalvoda, J. (2006): Geomorfologické členění reliéfu Čech (p. 79). Kartografie, Praha.

[4] Bezvodová, B., Demek, J., Zeman, A. (1985): Metody kvartérně geologického a geomorfologického výzkumu (p. 207). - SPN, Praha.

[5] Bruschi, V. M., Cendrero, A. (2005): Geosite Evaluation: Can we measure intangible values? - Italian Journal of Quaternary Sciences 18(1): 293-306.

[6] Cetiner, Z. S., Ertekin, C., Yigitbas, E. (2017): Evaluting Scientific Value of Geodiversity for Natural Protected Sites: the Biga Peninsula, Northwestern Turkey. - Geoheritage (on -line). DOI : 10.1007/s12371-017-0218-3.

[7] Cháb, J., Breitr, K., Fatka, O., Hladil, J., Kalvoda, J., Šimůnek, Z., Štroch, P., Vašíček, Z., Zajíc, J., Zapletal, J. (2008): Stručná geologie základu Českého masivu a jeho karbonského a permského pokryvu (p. 284). - Vydavatelství České geologické služby, Praha.

[8] Chábera, S., Huber, K. H. (1999): Beispiele kryogener Verwitterungs - und Abtragungsformen im Eisgarner Granit. - Sborník Jihočeského muzea v Českých Budějovicích. Př́rodní vědy 39(1-2): 5-17.

[9] Coates, D. R. (ed.) (1971): Environmental Geomorphology. - Proceedings Symposium, State University of New York, Binghamton, 262 p.

[10] Condorachi, D. (2011): Geomorphological mapping using GIS for large tableland areas an example for Fălciu Hills, in eastern Romania. - Carpathian Journal of Earth and Environmental Science 6(2): 115-124.

[11] Coratza, P, Bruschi, V. M., Piacentini, D., Saliba, D., Soldati, M. (2011): Recognition and Assessment of Geomorphosites in Malta at the Il-Majjistral Nature and History Park. - Geoheritage 3(3): 175-185.

[12] Coratza, P., Galve, J. P., Soldati, M., Tonelli, C. (2012): Recognition and assessment of sinkholes as geosites: lessons from the Island of Gozo (Malta). - Quaestiones Geographicae 31(1): 25-35

[13] Demek, J. (1972): Klasifikace a terminologie kryogenních tvarů. - Sborník ČSSZ 77(3): 303-309.

[14] Demek, J., Aristarkhova, L. B., Bashenina, N. V., Bélanger, J. R., Castiglioni, G. B., Dumitrashko, N. V., Galon, R., Gellert, J. F., Joly, F., Kudronovska, O., Kuznecova, T. P., Lukashov, A. A., Matoušek, A., Morin, J. M., Piotrovsky, R. J., Rudberd, S., Scholz, E., Simonov, Y. G., Tricart, J., Verstappen, H. Th. (1972): Manual of detailed geomorphological mapping (p. 344). - Academia, Praha.

[15] Demek, J. (1987): Obecná geomorfologie (p. 480). - Academia, Praha.

[16] Demek, J., Mackovčin, P. (eds.) (2006): Zeměpisný lexikon ČR: Hory a nížiny (p. 584). AOPK C̆R, Brno.

[17] French, H. M. (2007): The Periglacial Environment (p. 452). (3rd ed.). - Wiley, London.

[18] Goudie, A. S. (2004): Geomorphology: Definition and scope (pp. 428-435). - In: Goudie, A. S. (ed.) Encyclopedia of Geomorphology. Routledge Ltd, London.

[19] Goudie, S. A. (ed.) (2004a): Encyclopedia of Geomorphology (pp.1-578). (Vol. 1. A - I.) - Routledge Ltd, London. 
[20] [Goudie, S. A. (ed.) (2004b): Encyclopedia of Geomorphology (pp.579-1156). (Vol. 2. J - Z.) - Routledge Ltd, London.

[21] Heřmánek, R., Matějka, D. (1998): Granites of the Novohradské hory Mts. and surrounding area. - Acta Universitatis Carolinae Geologica 42: 262-263.

[22] Huber, K. H. (1999): Zum Formenchatz der Granitverwitterung und - abtragung im nordwestlichen Waldviertel (pp. 113-132). - In: Steininger, F. F. (ed.) Erdgeschichte des Waldviertels. Waldviertler Heimatbund. Horn, Austria.

[23] Kirchner, K., Roštínský, P. (2007): Geomorfologická inventarizace vybraných skalních útvarů v centrální části CHKO Žd’árské vrchy. - Universitas Ostraviensis, Acta Facultatis Rerum Naturalium, Geographia-Geologia 237(10): 48-64.

[24] Kirchner, K., Kubalíková, L. (2011): Evaluation of geoheritage in the Western part of Podyjí National Park, Czech Republic. - Revista de geomorfologie 13: 51-58.

[25] Kirchner, K., Kubalíková, L. (2013): Relief assessment methodology with respect to geoheritage based on example of the Deblínská vrchovina Highland. - In: Fialová, J., Kubíčková, H. Public recreation and landscape protection - with man and hand in hand. Conference proceeding. 1.-3. 5. 2013 Brno, Universita Mendeliana Brunensis, pp. 131141.

[26] Kubalíková, L. (2009): Block accumulations in the western part of the Podyjí National Park (Czech Republic): Preliminary analysis of their distribution - Moravian Geographical Reports 17(1): 49-55.

[27] Kubalíková, L. (2013): Geomorphosite assessment for geotourism purposes. - Czech Journal of Tourism 2(2): 80-104.

[28] Kubalíková, L., Kirchner, K. (2016): Geosite and geomorphosite assessment as a tool for geoconservation and geotourism purposes: a case study from Vizovická vrchovina Highland (eastern part of the Czech Republic). - Geoheritage 8: 5-14.

[29] Létal, A. (1998): Usage and building map symbols in PC ARC/INFO 3.4.2. Approach. Acta Universitatis Palackianae Olomoucensis, Facultas Rerum Naturalium, Geographica 35: 13-17.

[30] Malíček, J., Palice, Z. (2013): Lichens of the virgin forest reserve Zofinsky prales (Czech Republic) and surrounding woodlands. - Herzogia 26(2): 253-292.

[31] Migoń, P. (2016): Jizerské hory - an interplay of rock control, faulting and inland glaciation in the evolution of a granite terrain (pp. 165-175). - In: Pánek T, Hradecký, J. (eds.) Landscapes and Landforms of the Czech Republic. Springer, Dordrecht.

[32] Migoń, P., Różycka, M., Michniewicz, A. (2017): Conservation and geotourism perspectives at granite geoheritage sites of Waldviertel, Austria. - Geoheritage (on line) DOI: 10.1007/s12371-017-0219-2.

[33] Pánek, T., Hradecký, J. (eds.) (2016): Landscapes and Landforms of the Czech Republic. - In: Piotr, M. (ed.) World Geomorphological Landscapes. Springer International Publishing, Switzerland.

[34] Panizza, M. (2004): Environmental Geomorphology (pp. 318-320). - In: Goudie, A. S. (ed.) Encyclopedia of Geomorphology. Routledge Ltd, USA, Canada.

[35] Pavlíček, V. (2004): Geologie Novohradských hor. - In: Kubeš, J. (ed.) Krajina Novohradských hor - fyzicko-geografické složky krajiny (pp. 9-45). - Jihočeská univerzita, Pedagogická fakulta, České Budějovice.

[36] Pereira, P., Pereira, D., Alves, M. I. C. (2007): Geomorphosite assessment in Montesinho Natural Park (Portugal). - Geographica Helvetica 62(3): 159-168.

[37] Reynard, E., Fontana, G., Kozlik, L., Scapozza, C. (2007): A method for assessing the scientific and additional values of geomorphosites. - Geographica Helvetica 62(3): 148158.

[38] Reynard, E., Perret, A., Bussard, J., Grangier, L., Martin, S. (2016): Integrated Approach for the Inventory and Management of Geomorphological Heritage at the Regional Scale. Geoheritage 8(1): 43-60. 
[39] Rypl, J. (2013): Reliéf Pohořské hornatiny (Novohradské hory) se zaměřením na rozššřrení kryogenních tvarů. Ph.D thesis (p. 147). - Masarykova univerzita, Brno.

[40] Rypl, J. (2015): Geomorphologically Significant Sites of the Novohradské hory Mts. (Czech Republic) (p.111). - Lambert Academic Publishing, Czech Republic.

[41] Rypl, J., Kirchner, K., Dvořáčková, S. (2015): Geomorphological Inventory as a Tool for Proclaiming Geomorphosite (a Case Study Mt. Myslivna in the Novohradské hory Mts. Czech Republic). - Geoheritage 8(4): 393 - 400.

[42] Slaymaker, O. (ed.) (2000): Geomorphology, Human Activity and Global Environmental Change (p. 322). - John Wiley \& Sons, LTD, Chichester.

[43] Slaymaker, O., Spenser, T., Embleton-Hamann, C. (eds.) (2009): Geomorphology and global environmental change (p. 528). - Cambridge University Press, Cambridge.

[44] Serrano, E., Gonzáles-Trueba, J. J. (2005): Assessment of geomorphosites in natural protected areas: the Picos de Europa National Park (Spain). - Géomorphologie: relief, processus, environnement 1(3): 197-208.

[45] Smith, J. M., Paron, P., Griffiths, S. J. (2011): Geomorphological mapping: methods and applications (p. 612). - Elsevier, Amsterdam.

[46] Summerfield, M. (1991): Global geomorphology (p. 535). - University of Edinburgh, Edinburgh.

[47] Staník, E. (1991): Vysvětlivky k základní geologické mapě ČSFR 1:25,000, list 33-131 Nové Hrady (p. 43). - Český geologický ústav, Praha.

[48] Štykar, J. (2005): Biodiversity of forest plant communities within spruce stands conversion in vegetation tiers 4 and 5. - Ekologia Bratislava 24(4): 344-356.

[49] Trenhaile, A. S. (2007): Geomorphology: A Canadian perspective (p.498). - Oxford University Press, Toronto.

[50] Thomas, S. G. D., Goudie, A. (2000): The dictionary of physical geography (p. 610). Blackwell Publishing Ltd, Oxford.

[51] Vítek, J. (1995): Tvary zvětrávání a odnosu granodioritu ve vrcholových partiích Novohradských hor). - Uhlí-Rudy-Geologický průzkum 2(3): 94-95.

[52] Voženílek, V., Kirchner, K., Konečný, M., Kubíček, P., Létal, A., Petrová, A., Rothová, H., Sedlák, P. (2001): Integrace GPS/GIS v geomorfologickém výzkumu) (p. 185). Univerzita Palackého v Olomouci, Olomouc.

[53] Vrána, S. (1987): Základní geologická mapa ČSSR, list 32-244 Benešov nad Černou. Ústřední ústav geologický, Praha. 